\title{
Result Category
}

National Cancer Institute

\section{Source}

National Cancer Institute. Result Category. NCI Thesaurus. Code C82498.

A classification of a result. 